
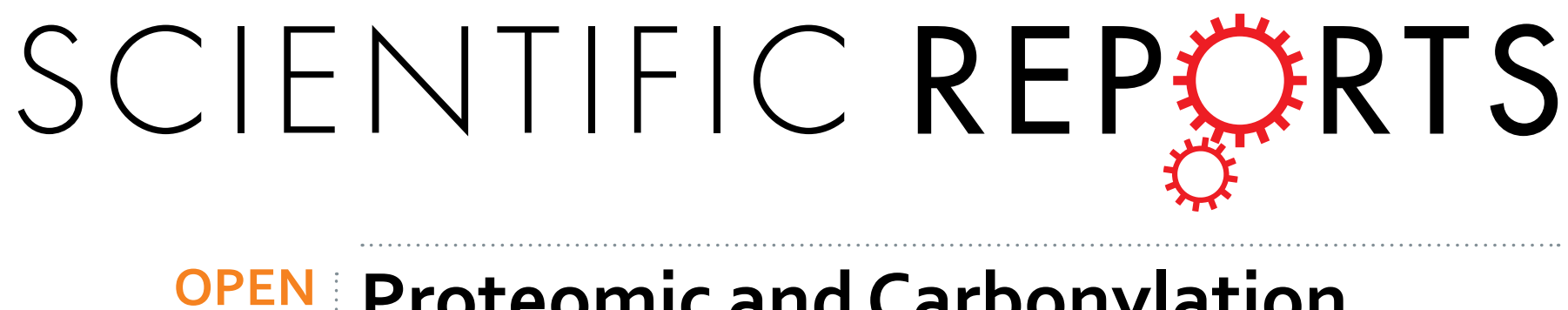

\title{
Proteomic and Carbonylation Profile Analysis at the Critical Node of Seed Ageing in Oryza sativa
}

Received: 16 September 2016

Accepted: 07 December 2016

Published: 17 January 2017
Guangkun Yin ${ }^{1, *}$, Xia Xin ${ }^{1, *}$, Shenzao Fu $u^{1,2,{ }^{*}}$, Mengni An ${ }^{1}$, Shuhua Wu ${ }^{1}$, Xiaoling Chen ${ }^{1}$, Jinmei Zhang ${ }^{1}$, Juanjuan $\mathrm{He}^{1}$, James Whelan ${ }^{3}$ \& Xinxiong Lu ${ }^{1}$

The critical node (CN), which is the transition from the plateau phase to the rapid decreasing phase of seed ageing, is extremely important for seed conservation. Although numerous studies have investigated the oxidative stress during seed ageing, information on the changes in protein abundance at the $\mathrm{CN}$ is limited. In this study, we aimed to investigate the abundance and carbonylation patterns of proteins at the $\mathrm{CN}$ of seed ageing in rice. The results showed that the germination rate of seeds decreased by less than $20 \%$ at the $\mathrm{CN}$; however, the abundance of 112 proteins and the carbonylation levels of 68 proteins markedly changed, indicating oxidative damage. The abundance and activity of mitochondrial, glycolytic, and pentose phosphate pathway proteins were reduced; consequently, this negatively affected energy production and germination. Proteins related to defense, including antioxidant system and heat shock proteins, also reduced in abundance. Overall, energy metabolism was reduced at the $\mathrm{CN}$, leading to a decrease in the antioxidant capacity, whereas seed storage proteins were up-regulated and carbonylated, indicating that the seed had a lower ability to utilize seed storage proteins for germination. Thus, the significant decrease in metabolic activities at the $\mathrm{CN}$ might accelerate the loss of seed viability.

A notable characteristic of seed viability is the reverse $S$-shaped survival curve during ageing, which includes a plateau phase (Phase I; P-I), followed by a rapid decreasing phase (Phase II; P-II) and a slow decreasing phase (Phase III; P-III). The transformation from P-I to P-II is defined as the critical node (CN), which is highly important for seed conservation ${ }^{1}$. The average germination of approximately 42,000 diverse accessions stored for 16 to 81 years at the National Center for Genetic Resources Preservation, USA has been decreased by $42 \%{ }^{2}$. The average germination rate of peanut (stored for 34 years), soybean (stored for 36 years), wheat (stored for 43.6 years), and barley (stored for 44.4 years) is $6 \%, 21 \%, 73 \%$, and $86 \%$, respectively ${ }^{3}$. Similar results have been also reported by the Genebank of the Leibniz Institute of Plant Genetics and Crop Plant Research (IPK), Germany ${ }^{4}$. Rice is extremely important food crop. One of main aims in genebanks is maintaining the rice seed safe conservation. At the T.T. Chang Genetic Resources Center in International Rice Research Institute, 183 rice accessions stored up to 30 years showed more than $70 \%$ germination $^{5}$, and more than $93 \%$ of seed lots produced in 1980 still maintained $85 \%$ germination after 33 years in storage ${ }^{6}$. Owing to the reduction in seed viability, the regeneration of genetic resources is considered crucial for maintaining genetic integrity. Previous studies have shown that seed regeneration needs to be carried out prior to the $\mathrm{CN}$ in order to prevent a large decrease in viability, which can lead to changes in genetic composition ${ }^{7,8}$. Previously, we showed that the mitochondrial ultrastructure of seed at the CN is abnormal owing to the decreased oxygen consumption as well as the decreased activity of cytochrome $c$ oxidase and malate dehydrogenase $(\mathrm{MDH})^{1}$.

The role of reactive oxygen species (ROS) in the loss of seed viability has been well investigated. During natural or accelerated ageing, the levels of seed antioxidative enzymes (e.g., superoxide dismutase, SOD; catalase, CAT; ascorbate peroxidase, APX; and glutathione reductase, GR) and antioxidants (ascorbic acid and glutathione) decrease, leading to the accumulation of ROS and consequently oxidative damage ${ }^{9,10}$. The proteomic analysis of aged maize seeds indicated that the loss of seed viability loss is related to ROS damage ${ }^{11}$. The reduction

${ }^{1}$ National Genebank, Institute of Crop Science, Chinese Academy of Agricultural Sciences, Beijing 100081, China. ${ }^{2}$ China National Rice Research Institute, Hangzhou 310006, China. ${ }^{3}$ Australian Research Council Centre of Excellence in Plant Energy Biology, School of Life Science, La Trobe University, Bundoora, Victoria 3083, Australia. ${ }^{*}$ These authors contributed equally to this work. Correspondence and requests for materials should be addressed to J.W. (email: J.Whelan@LaTrobe.edu.au) orX.L. (email: luxinxiong@caas.cn) 
in antioxidant capacity, i.e., decrease in the expression of CAT1, APX1, and MDHAR1 may be responsible for the loss of rice seed viability during storage ${ }^{12}$. The mitochondrial structure and function alter in aged seeds. For instance, in aged soybean seeds, the mitochondrial ascorbic acid and glutathione cycle activity decreased, leading to elevated ROS accumulation ${ }^{13}$. The aged seed induces dynamic changes in mitochondrial physiology via the increased ROS production, resulting in an irreversible loss of seed viability ${ }^{14}$. Seed possess many repair enzymes, such as PROTEIN l-ISOASPARTYL O-METHYLTRANSFERASE, for proventing age-induced ROS accumulation to improve seed vigor and longevity ${ }^{15}$.

ROS accumulation can induce the formation of protein carbonyls that affect enzyme activity and lead to ageing or death ${ }^{16,17}$. Numerous studies have reported that protein carbonylation contributes to leaf and fruit senescence as well as the decreased rate of seed germination ${ }^{18-20}$. In Arabidopsis, HSP70 and LEA were carbonylated after ageing treatment ${ }^{21}$, whereas seed storage proteins (SSPs) were carbonylated during storage ${ }^{22}$. In this study, we aimed to determine the changes in protein abundance and protein carbonylation at the $\mathrm{CN}$ of seed ageing in rice. The carbonylated protein patterns were analyzed by two-dimensional (2D) gel electrophoresis followed by western blotting with antidinitrophenyl hydrazone (DNP) antibodies. The carbonylation level and pattern of several proteins might be indicators of seed ageing, and could help to improve seed storage management.

\section{Results}

Proteomic and carbonylation profile analysis at the $\mathrm{CN}$. In our previous study, rice seed vigor loss displayed a P-I, and then experienced a rapid decreasing phase after $84 \%$ germination (P-II). Therefore, we chose the seed germination percentage at $84 \%$ as the critical node ${ }^{1}$. Seed vigor was analyzed from maximum to the $\mathrm{CN}$, as it is this stage that is extremely important for safe conservation of seeds in genebank. This differed to previous studies in Arabidopsis ${ }^{21}$, maize ${ }^{11}$, and Brassica napus seeds ${ }^{23}$ where comparison was made at the end of Phase II.

Proteomic and carbonylation profile analysis was carried out to determine the impact of oxidative stress at the CN. Protein profiles of rice embryos was extracted from $97 \%$ (control), $92 \%$ and $84 \%$ germination percentage after $0 \mathrm{~d}, 3 \mathrm{~d}$, and $4 \mathrm{~d}$ aged treatment, respectively, and separated by gel electrophoresis using immobilized $\mathrm{pH}$ gradient (IPG) strips in isoelectric focusing (IEF). Three biological repeats were used for either gels or blots of each sample. More than 700 protein spots were detected on $12 \%(\mathrm{v} / \mathrm{v})$ sodium dodecyl sulfate polyacrylamide gel electrophoresis (SDS-PAGE) gels by PDQuest 8.0 (Fig. 1). The abundance of 112 protein spots showed a change higher than 1.5-fold at the CN which MOWSE score were higher than 65 (Table 1). Of them, 78 downregulated proteins (D1-D78) and 17 upregulated proteins (U1-U17) were identified in all treated seeds; 11 upregulated proteins (U18-U28) were uniquely detected in 3-d aged seeds; and six upregulated proteins (U29-U34) were uniquely detected in 4 - $\mathrm{d}$ aged seeds (Tables 1 and 2). Figure 2 shows the change pattern of different proteins related to energy, defense, metabolism, growth or division, transcription, and other unknown functions ${ }^{24}$.

To better understand protein carbonylation at the $\mathrm{CN}$, we performed in-strip derivatization with 2,4-dinitrophenylhydrazine (DNPH) followed by SDS-PAGE and immumochemical detection of carbonylated proteins. Figure 3 shows carbonylated proteins from rice seeds in $2 \mathrm{D}$ blots. The level of carbonylated proteins on the polyvinylidene difluoride (PVDF) membrane was normalized to the protein level of the corresponding protein spot on $2 \mathrm{D}$ gels, and only reproducible differences were considered to be changes. The results showed that $32(\mathrm{C} 1-\mathrm{C} 32)$ out of 78 downregulated proteins and 8 out of 36 upregulated proteins (C33-C40) displayed significant carbonylation. Additionally, 11 upregulated proteins (C41-C51) and 17 downregulated proteins (C52-C68) showed no significant change in abundance on 2D gels, but displayed significant changes in carbonylation (Table 3). Overall, seed proteins underwent carbonylation at the CN.

Downregulated proteins at the CN. The 78 downregulated proteins were related to energy (29\%), defense $(21 \%)$, metabolism $(14 \%)$, protein synthesis $(8 \%)$, protein destination and storage $(6 \%)$, transcription $(5 \%)$, growth or division (4\%), secondary metabolism (3\%), transporting (1\%), signal transduction (1\%), and other unknown functions (2\%) (Fig. 2A). Additionally, carbonylation was observed among those proteins at the CN, further suggesting that the related functions could be disrupted.

Proteins related to energy metabolism. A total of 16 downregulated proteins were related to energy metabolism (Table 1). The $\beta$-ATP synthase subunit ( $\beta$ ATP), MDH, and succinate dehydrogenase (SDH) showed decrease in abundance (D14, D19, and D48) and significant carbonylation (C12, C16, and C27) (Table 1). To better understand protein expression at the $\mathrm{CN}$, the activity of $\mathrm{MDH}$ was measured in aged seeds after imbibition for $48 \mathrm{~h}$. As compared to the control, the activity of $\mathrm{MDH}$ showed a decrease by $11 \%$ and $20 \%$ in 3 - $\mathrm{d}$ and 4 -d aged seeds, respectively (Fig. 4A), which was consistent with the decrease in abundance. $M D H 1$ also displayed a steady downregulation with ageing (Fig. 5A). Compared with the control, SDH1 showed a decrease by $16 \%$ and $40 \%$ in 3-d and 4-d aged seeds, respectively (Fig. 5B). The immunodetection of the $\beta$ ATP subunit showed a significant decrease at the CN (Fig. 5G). Compared with the control, $\beta A T P$ showed a decrease by $25 \%$ and $45 \%$ in 3 -d and 4 -d aged seeds, respectively (Fig. 5C). These results indicated that mitochondrial metabolism significantly decreased at the $\mathrm{CN}$.

Seven proteins of the glycolytic pathway, including phospoglycerate mutase (D4), pyruvate decarboxylase (PDC, D8), triosephosphate isomerase (D29 and D53), D-glyceraldehyde 3-phosphate enolase (D58 and D63), and pyrophosphate-dependent phosphofructokinase (D62) were downregulated, indicating that glycolytic metabolism was also reduced at the CN. Of these proteins, D4, D8, D29, and D63 also showed significant carbonylation (C4, C7, C30 and C31) (Table 1). Compared with the control, the activity of PDC showed a decrease by $23 \%$ and $30 \%$ in $3-d$ and $4-d$ aged seeds, respectively (Fig. 4B). In this study, PDC1 did not show any significant change at the $\mathrm{CN}$ (Fig. 5D). Additionally, 6-phosphogluconate dehydrogenase (6PGD, D7) of the oxidative pentose phosphate pathway (PPP) showed a decrease in abundance and significant carbonylation (C6). Compared 


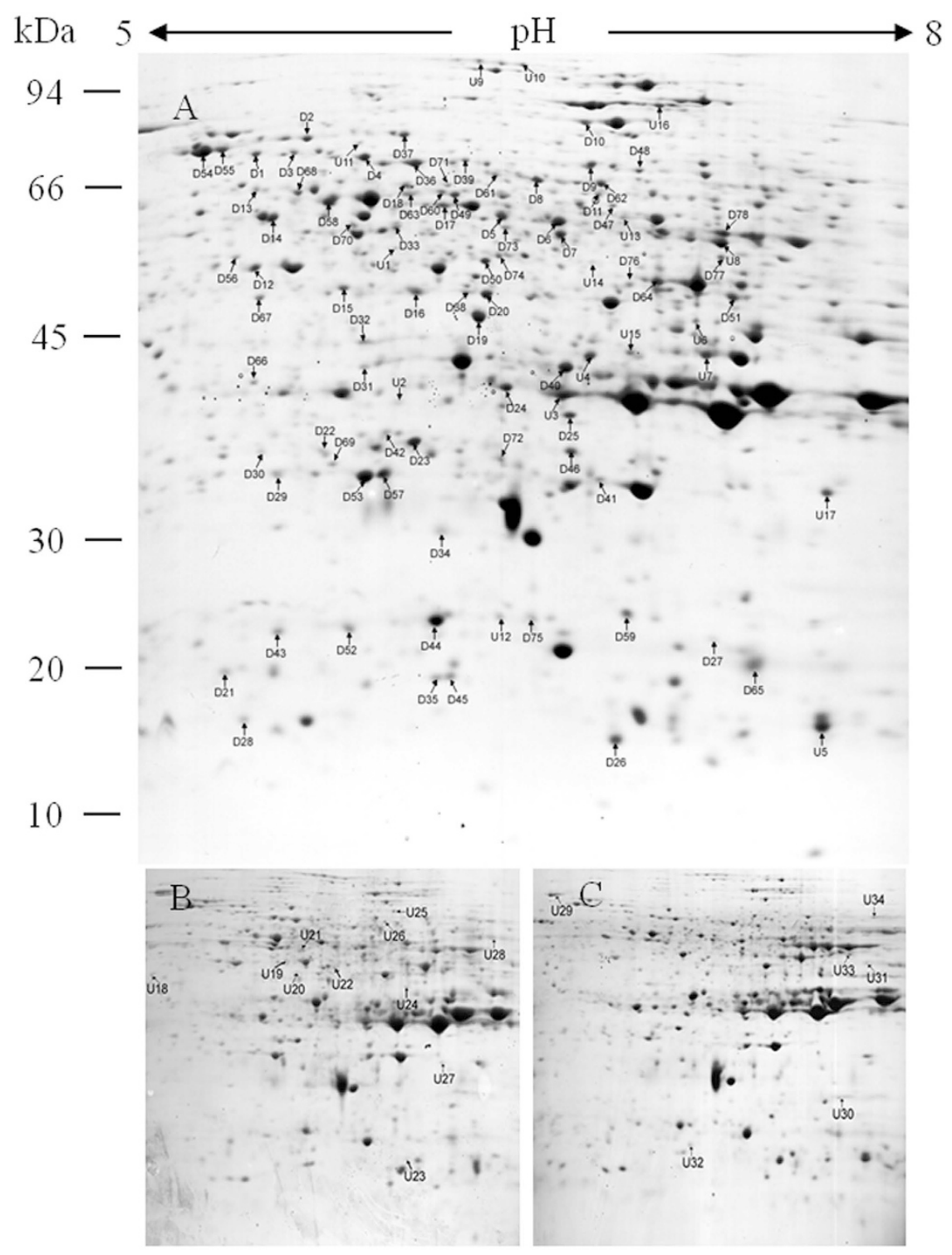

Figure 1. Representative isoelectric focusing (IEF)/dodecyl sulfate polyacrylamide gel electrophoresis (SDSPAGE) separation gels of proteins from $0 \mathrm{~d}(\mathbf{A}), 3 \mathrm{~d}(\mathbf{B})$ and $4 \mathrm{~d}(\mathbf{C})$ aged rice seeds after imbibition for $48 \mathrm{~h}$. Total $500 \mu \mathrm{g}$ protein were separated by immobilized $\mathrm{pH}$ gradient (IPG) strips and $12 \%$ (w/v) SDS-PAGE gels. Protein codes correspond to those in Tables 1,2 and 3. Number on the left represents the apparent molecular mass. Number above the gels represents the $\mathrm{pI}$ of separated protein spot. U, upregulation; $\mathrm{D}$, downregulation.

with the control, the activity of 6PGD showed a decrease by $15 \%$ and $33 \%$ in 3 -d and 4 -d aged seeds, respectively, whereas 6 PGD1 showed a decrease by $37 \%$ and $56 \%$, respectively (Figs $4 \mathrm{C}$ and $5 \mathrm{E}$ ). These results indicated that $\mathrm{PPP}$ was significantly inhibited at the $\mathrm{CN}$.

Proteins related to defense. In this study, 12 downregulated proteins were related to defense, indicating the decreased ability of aged seeds to combat oxidative stress. Compared with the control, the activity of ascorbate peroxidase 1 (APX, D57) decreased by $47 \%$ and $33 \%$ in $3-\mathrm{d}$ and 4 -d aged seeds, respectively (Fig. 4D). APX1 showed a steady decrease with ageing (Fig. 5F). Additionally, the reduced abundance in cytosolic APX proteins at the $\mathrm{CN}$ was confirmed by immunodetection using the cytosolic APX antibody (Fig. 5G) and indicated ROS accumulation at the $\mathrm{CN}$ of seed ageing. Compared with the control, the activity of glutathione S-transferase (GST, D46) decreased by $87 \%$ and $70 \%$ in 3-d and 4 - $\mathrm{d}$ aged seeds, respectively (Fig. $4 \mathrm{E}$ ), negatively affecting the ability of the antioxidant defense system. GST showed a decrease in abundance and significant carbonylation (C26). Five heat shock proteins (HSPs), including HSP70 (D2, D54, and D55), 17.9-kDa class I HSP (D13), 18.0-kDa class II HSP (D44), and two chaperonins (D13 and D60) significantly downregulated at the CN, whereas the HSP D2 and D44 and the chaperonin D13 showed significant carbonylation (C2, C25 and C11). 


\begin{tabular}{|c|c|c|c|c|c|c|}
\hline \multirow[b]{2}{*}{ Spot } & \multirow[b]{2}{*}{ Protein name } & \multirow[b]{2}{*}{ Accession No. } & \multirow[b]{2}{*}{ Scores } & \multicolumn{2}{|c|}{ Fold } & \multirow[b]{2}{*}{ Carbonylation } \\
\hline & & & & 0d/3d & 0d/4d & \\
\hline \multicolumn{7}{|c|}{ Energy } \\
\hline D1 & Vacuolar proton-ATPase & NP_001058280.1 & 890 & 1.85 & 4.54 & $\mathrm{C} 1$ \\
\hline $\mathrm{D} 4$ & Phospoglycerate mutase & NP_001044625.1 & 1094 & 1.59 & 2.74 & $\mathrm{C} 4$ \\
\hline D5 & ATP synthase lipid-binding protein & YP_002000594.1 & 773 & 1.82 & 2.55 & $\mathrm{C} 5$ \\
\hline D6 & ATP synthase lipid-binding protein & YP_002000594.1 & 744 & 1.71 & 3.01 & \\
\hline D7 & 6-phosphogluconate dehydrogenase 1 & NC_029261.1 & 1067 & 2.93 & 5.99 & C6 \\
\hline D8 & Pyruvate decarboxylase & BAC20138.1 & 446 & 1.49 & 2.29 & $\mathrm{C} 7$ \\
\hline D14 & ATP synthase subunit beta & NP_001043900.1 & 1482 & 1.59 & 2.11 & $\mathrm{C} 12$ \\
\hline D19 & Malate dehydrogenase & NP_001064860.1 & 903 & 1.35 & 30.02 & $\mathrm{C} 16$ \\
\hline D22 & Cyt-RPEase & NP_001063604.2 & 187 & 1.93 & 5.13 & \\
\hline $\mathrm{D} 29$ & Triosephosphate isomerase & AAB63603.1 & 689 & 1.29 & 3.06 & \\
\hline D30 & Carboxymethylenebutenolidase-like protein & NP_001043244.1 & 536 & 1.16 & 1.42 & \\
\hline D36 & Pyruvate decarboxylase 2 & NP_001049811.1 & 615 & 1.18 & 2,17 & $\mathrm{C} 21$ \\
\hline $\mathrm{D} 48$ & Succinate dehydrogenase flavoprotein subunit & NP_001058845.1 & 123 & 1.26 & 1.82 & $\mathrm{C} 27$ \\
\hline D53 & Triosephosphate isomerase & AAB63603.1 & 995 & 1.26 & 2.44 & $\mathrm{C} 30$ \\
\hline D58 & Enolase & AAC49173.1 & 1075 & 1.79 & 1.98 & $\mathrm{C} 31$ \\
\hline D61 & Pyruvate decarboxylase 1 & NC_029260.1 & 147 & 1.19 & 2.39 & \\
\hline D62 & Phosphofructokinase beta subunit & NP_001057284.1 & 596 & 1.04 & 2.66 & \\
\hline D63 & Beta-enolase & AAC49173.1 & 269 & 2.34 & 1.48 & \\
\hline D64 & ADH1 & ADH03842.1 & 997 & 2.36 & 1.87 & C32 \\
\hline D69 & Vacuolar ATP synthase $16 \mathrm{kDa}$ proteolipid subunit & AAO72561.1 & 145 & $\infty$ & $\infty$ & \\
\hline D70 & Ketol-acid reductoisomerase & NP_001043738.1 & 186 & $\infty$ & $\infty$ & \\
\hline D74 & UDP-glucose 6-dehydrogenase 3 & NP_001051328.1 & 568 & $\infty$ & $\infty$ & \\
\hline D78 & Glyceraldehyde-3-phosphate dehydrogenase 2, & NP_001053139.1 & 451 & $\infty$ & $\infty$ & \\
\hline \multicolumn{7}{|c|}{ disease/defense } \\
\hline D2 & $70 \mathrm{kDa}$ heat shock protein & ABF95267.1 & 502 & 1.51 & 2.33 & $\mathrm{C} 2$ \\
\hline D13 & Chaperonin CPN60-1, mitochondrial & NP_001048938.1 & 248 & 2.40 & 3.24 & C11 \\
\hline D26 & Dehydration stress-induced protein & NP_001064434.1 & 192 & 1.49 & 2.58 & \\
\hline D38 & Salt tolerance protein 5 & NP_001057221.1 & 153 & 1.16 & 4.14 & $\mathrm{C} 23$ \\
\hline D44 & $17.9 \mathrm{kDa}$ class I heat shock protein & NP_001049657.1 & 686 & 1.06 & 1.51 & $\mathrm{C} 25$ \\
\hline D46 & Glutathione S-transferase 2 & NP_001044339.1 & 282 & 1.39 & 2.46 & $\mathrm{C} 26$ \\
\hline D52 & $18.0 \mathrm{kDa}$ class II heat shock protein & NP_001042231.1 & 339 & 1.17 & 1.88 & \\
\hline D54 & $70 \mathrm{kDa}$ heat shock protein & ABA95501.2 & 813 & 1.49 & 2.55 & \\
\hline D55 & $70 \mathrm{kDa}$ heat shock protein & NP_001044757.1 & 725 & 1.46 & 2.42 & \\
\hline D56 & Silver leaf whitefly-induced protein 1 & NP_001047794.1 & 653 & 1.38 & 1.50 & \\
\hline D57 & L-ascorbate peroxidase 1 & NP_001049769.1 & 639 & 3.32 & 10.89 & \\
\hline D59 & Cold shock domain protein 2 & NP_001060914.1 & 525 & 1.91 & 1.94 & \\
\hline D60 & TCP-1/cpn60 chaperonin & AAT77033.1 & 338 & 1.28 & 1.82 & \\
\hline D72 & Germin-like protein 8-2 & AAC04834.1 & 136 & $\infty$ & $\infty$ & \\
\hline D73 & GDP-mannose 3,5-epimerase 2 & NP_001068183.1 & 290 & $\infty$ & $\infty$ & \\
\hline D75 & Germin-like protein 8-2 & AAC04834.1 & 106 & $\infty$ & $\infty$ & \\
\hline \multicolumn{7}{|c|}{ Metabolism } \\
\hline D10 & 5-methyltetrahydropteroyltriglutamate-homocysteine methyltransferase & ABG22095.1 & 1087 & 2.89 & 4.92 & C9 \\
\hline D15 & Glutamine synthetase cytosolic isozyme 1-1 & NP_001048045.1 & 328 & 1.88 & 3.78 & $\mathrm{C} 13$ \\
\hline D16 & Reversibly glycosylated polypeptide & CAA77235.1 & 178 & 1.63 & 9.04 & \\
\hline D17 & Methylmalonate semi-aldehyde dehydrogenase & NP_001059082.1 & 412 & 2.23 & 4.65 & C14 \\
\hline D18 & Ketol-acid reductoisomerase & NP_001043738.1 & 663 & 1.50 & 4.47 & $\mathrm{C} 15$ \\
\hline D20 & Reversibly glycosylated polypeptide & CAA77235.1 & 906 & 1.53 & 2.93 & $\mathrm{C} 17$ \\
\hline D37 & Phosphoglucomutase & NP_001051066.1 & 470 & 1.09 & 6.36 & $\mathrm{C} 22$ \\
\hline D41 & Proteasome subunit beta type- 1 & NP_001063603.1 & 663 & 1.18 & 2.33 & \\
\hline D47 & Inosine-5'-monophosphate dehydrogenase 1 & AAK09225.1 & 598 & 1.17 & 1.94 & \\
\hline D49 & Leucyl-cystinyl aminopeptidase & Q6K669.1 & 1325 & 1.37 & 3.83 & $\mathrm{C} 28$ \\
\hline D50 & S-adenosylmethionine synthase & P93438.1 & 638 & 1.61 & 2.21 & \\
\hline \multicolumn{7}{|c|}{ protein synthesis } \\
\hline D32 & $60 \mathrm{~S}$ acidic ribosomal protein $\mathrm{P} 0$ & NP_001060923.1 & 531 & 1.09 & 2.49 & C19 \\
\hline $\mathrm{D} 40$ & Guanine nucleotide-binding protein subunit beta & NP_001043910.1 & 1053 & 1.25 & 1.40 & \\
\hline
\end{tabular}




\begin{tabular}{|c|c|c|c|c|c|c|}
\hline \multirow[b]{2}{*}{ Spot } & \multirow[b]{2}{*}{ Protein name } & \multirow[b]{2}{*}{ Accession No. } & \multirow[b]{2}{*}{ Scores } & \multicolumn{2}{|c|}{ Fold } & \multirow[b]{2}{*}{ Carbonylation } \\
\hline & & & & $0 \mathrm{~d} / 3 \mathrm{~d}$ & $0 \mathrm{~d} / 4 \mathrm{~d}$ & \\
\hline D65 & Bowman Birk trypsin inhibitor & BAD52869.1 & 107 & 1.37 & 1.52 & \\
\hline D67 & Succinyl-CoA ligase [ADP-forming] subunit beta & NP_001047463.1 & 145 & $\infty$ & $\infty$ & \\
\hline D68 & Mitochondrial processing peptidase beta subunit & NP_001049357.1 & 194 & $\infty$ & $\infty$ & \\
\hline D76 & $\begin{array}{l}\text { Mitochondrial import inner membrane translocase subunit Tim17/Tim22/Tim23 family } \\
\text { protein }\end{array}$ & NP_001049884.1 & 106 & $\infty$ & $\infty$ & \\
\hline \multicolumn{7}{|c|}{ protein destination and storage } \\
\hline D28 & Cupin family protein & AAS07324.1 & 394 & 1.66 & 2.97 & \\
\hline D42 & Cupin family protein & ABF95817.1 & 202 & 1.21 & 2.92 & \\
\hline D43 & Cupin family protein & ABF95817.1 & 376 & 1.31 & 1.68 & \\
\hline D71 & Cupin family protein & ABF95817.1 & 236 & $\infty$ & $\infty$ & \\
\hline D77 & Cupin family protein & ABF95817.1 & 144 & $\infty$ & $\infty$ & \\
\hline \multicolumn{7}{|c|}{ Transcription } \\
\hline $\mathrm{D} 21$ & Elicitor-inducible protein EIG-J7 & NP_001048145.1 & 232 & 1.52 & 5.34 & \\
\hline D35 & Glycine-rich RNA-binding protein 7 & AAT85299.1 & 464 & 1.29 & 3.72 & \\
\hline D39 & Asparagine-tRNA ligase & NP_001043066.1 & 460 & 1.14 & 2.74 & $\mathrm{C} 24$ \\
\hline D45 & Glycine-rich RNA-binding protein GRP1A & NP_001067344.1 & 64 & 1.49 & 1.66 & \\
\hline \multicolumn{7}{|c|}{ growth/division } \\
\hline D12 & Actin & BAB63635.1 & 700 & 1.43 & 3.82 & $\mathrm{C} 10$ \\
\hline D51 & Late embryogenesis abundant protein 1 & A2XG55.2 & 355 & 1.21 & 1.35 & $\mathrm{C} 29$ \\
\hline D66 & Spermidine synthase 1 & NP_001059438.1 & 183 & $\infty$ & $\infty$ & \\
\hline \multicolumn{7}{|c|}{ secondary metabolism } \\
\hline D31 & NADH-dependent enoyl-ACP reductase & NP_001061557.1 & 570 & 1.31 & 6.18 & \\
\hline D34 & Lactoylglutathione lyase & NP_001055113.1 & 186 & 1.14 & 4.01 & \\
\hline \multicolumn{7}{|c|}{ Transporters } \\
\hline D9 & ECF transporter A component EcfA & BAD11555.1 & 777 & 1.72 & 3.95 & $\mathrm{C} 8$ \\
\hline \multicolumn{7}{|c|}{ signal transduction } \\
\hline D33 & GDP dissociation inhibitor & NP_001055566.1 & 550 & 1.71 & 2.61 & $\mathrm{C} 20$ \\
\hline \multicolumn{7}{|c|}{ unclear classification } \\
\hline D3 & Os09g0491772 protein & NP_001175918.1 & 241 & 1.54 & 2.91 & $\mathrm{C} 3$ \\
\hline D11 & OSJNBa0010H02.6 protein & NP_001053500.1 & 748 & 1.67 & 3.05 & \\
\hline D23 & Uncharacterized protein & NP_001056364.1 & 803 & 1.32 & 1.90 & \\
\hline D24 & OSJNBa0004N05.4 protein & CAE03380.1 & 608 & 1.42 & 2.44 & $\mathrm{C} 18$ \\
\hline D25 & Uncharacterized protein $\mathrm{P} 0435 \mathrm{H} 01.4$ & NP_001044131.1 & 654 & 1.53 & 2.07 & \\
\hline D27 & Uncharacterized protein P0036D10.5 & NP_001174164.1 & 238 & 1.46 & 2.57 & \\
\hline
\end{tabular}

Table 1. Proteins with significantly decreased abundance at the critical node in 0 -d, 3-d, and 4-d aged rice seeds. Mascot scores $>65$ are statistically significant at $p<0.05$.

Upregulated proteins at the CN. Compared with the control, 31 upregulated proteins were related to storage, energy, disease and defense, metabolism, protein synthesis, growth and division, and other unknown functions (Fig. 2B). SSPs formed the largest group of upregulated proteins that included globuline, glutelin, and cupin (Table 2), which showed various experimental molecular weights, indicating that SSPs were post-translationally modified or broken down (Fig. 3). In this study, we also identified 17 SSPs that displayed significant carbonylation, of which 10 were upregulated, whereas the rest showed no change in abundance (Tables 2 and 3 ).

\section{Discussion}

The viability of aged seeds is an important aspect for maintaining genetic diversity during seed storage. In this study, we demonstrated the occurrence of oxidative damage that primarily affects the abundance of proteins related to energy generation, metabolism, and defense. These findings were in agreement with previous studies in Arabidopsis, which showed that proteins related to energy, metabolism, and defense play key roles in seed maintenance and are downregulated at the $\mathrm{CN}^{21,22}$. The changes occurring in protein abundance appeared to be related to oxidative stress ${ }^{25,26}$, resulting in an inability to utilize seed storage proteins, as the latter increased in abundance at the $\mathrm{CN}$.

Proteins related to energy metabolism formed the largest group of downregulated proteins (Fig. 2A). The capacity of energy supply is highly important for seed germination and seedling growth, since large amounts of energy are needed prior to the establishment of photosynthesis in the plant ${ }^{27}$. Previous studies in Arabidopsis reported that one of the earliest events during germination is the upregulation of approximately 600 genes that encode proteins related to mitochondrial functions and are critical for germination ${ }^{28,29}$. A variety of mitochondrial mutants involved in electron transport showed slow germination rates or high seedling lethality ${ }^{28}$. The downregulated proteins of mitochondria were observed by carbonylated modification, including $\beta$ ATP, MDH 


\begin{tabular}{|c|c|c|c|c|c|c|}
\hline \multirow[b]{2}{*}{ Spot } & \multirow[b]{2}{*}{ Protein name } & \multirow[b]{2}{*}{ Accession No. } & \multirow[b]{2}{*}{ Scores } & \multicolumn{2}{|c|}{ Fold } & \multirow[b]{2}{*}{ Carbonylation } \\
\hline & & & & $3 \mathrm{~d} / 0 \mathrm{~d}$ & $4 d / 0 d$ & \\
\hline \multicolumn{7}{|c|}{ protein destination and storage } \\
\hline U14 & Glutelin type-A 2 & BAC77349.1 & 362 & 1.41 & 2.20 & C39 \\
\hline U3 & Cupin family protein & NP_001051533.1 & 554 & 1.01 & 2.35 & C34 \\
\hline $\mathrm{U} 4$ & Cupin family protein & NP_001051533.1 & 438 & 1.74 & 4.09 & \\
\hline U15 & Globulin-like protein & AAM33459.2 & 472 & 1.63 & 1.67 & \\
\hline U5 & Glutelin & NP_001046769.1 & 205 & 1.32 & 3.22 & \\
\hline U11 & Glutelin type-A 2 & CAA38211.1 & 274 & 1.83 & 2.81 & \\
\hline U8 & Vicilin storage protein & AAM33459.2 & 479 & 2.42 & 4.04 & \\
\hline U18 & Cupin family protein & NP_001051533.1 & 511 & $\infty$ & 0 & \\
\hline U27 & Cupin family protein & NP_001173574.1 & 198 & $\infty$ & 0 & \\
\hline $\mathrm{U} 28$ & Cupin family protein & BAC77349.1 & 425 & $\infty$ & 0 & \\
\hline U32 & Globulin-like protein & AAM33459.2 & 371 & 0 & $\infty$ & \\
\hline \multicolumn{7}{|c|}{ energy } \\
\hline U1 & Pullulanase & ACY56106.1 & 161 & 1.95 & 3.18 & \\
\hline U9 & H0806H05.4 protein & CAC09471.2 & 542 & 1.42 & 2.62 & C35 \\
\hline U10 & H0806H05.4 protein & CAC09471.2 & 312 & 3.31 & 5.48 & $\mathrm{C} 36$ \\
\hline U12 & 1,4-alpha-glucan-branching enzyme & BAA01584.1 & 115 & 1.14 & 1.98 & C37 \\
\hline U21 & ATP-citrate synthase alpha chain protein & NP_001067052.1 & 196 & $\infty$ & 0 & \\
\hline U29 & Peroxiredoxin-2C & NP_001043845.1 & 276 & 0 & $\infty$ & \\
\hline U30 & Peroxiredoxin-2C & NP_001043845.1 & 509 & 0 & $\infty$ & \\
\hline U34 & Nucleoside diphosphate kinase & NP_001065404.1 & 246 & 0 & $\infty$ & \\
\hline \multicolumn{7}{|c|}{ disease/defense } \\
\hline $\mathrm{U} 2$ & Heat shock protein $90-1$ & BAD04054.1 & 205 & 1.56 & 2.16 & $\mathrm{C} 33$ \\
\hline U6 & ABA-responsive protein & ABA98234.1 & 156 & 1.68 & 3.26 & \\
\hline $\mathrm{U} 22$ & GDP-mannose 3,5-epimerase 2 & NP_001068183.1 & 195 & $\infty$ & 0 & \\
\hline $\mathrm{U} 23$ & Dehydration stress-induced protein & NP_001057177.1 & 170 & $\infty$ & 0 & \\
\hline \multicolumn{7}{|c|}{ signal transduction } \\
\hline U13 & Adenosine kinase & BAC02723.1 & 169 & 1.39 & 1.79 & $\mathrm{C} 38$ \\
\hline U17 & GTP-binding nuclear protein Ran-2 & NP_001056390.1 & 553 & 2.06 & 2.86 & $\mathrm{C} 40$ \\
\hline \multicolumn{7}{|c|}{ metabolism } \\
\hline U16 & Sucrose synthase 1 & NP_001050319.1 & 103 & 2.21 & 3.56 & \\
\hline \multicolumn{7}{|c|}{ growth/division } \\
\hline U19 & Meiotic recombination protein SPO11-1 & NP_001067760.1 & 101 & $\infty$ & 0 & \\
\hline \multicolumn{7}{|c|}{ Unclear classification } \\
\hline U7 & Os03g0327600 protein & NP_001049995.1 & 470 & 1.60 & 2.16 & \\
\hline U20 & OSJNBa0044M19.9 protein & NP_001052622.1 & 150 & $\infty$ & 0 & \\
\hline U31 & Os05g0468800 protein & NP_001055802.2 & 409 & 0 & $\infty$ & \\
\hline
\end{tabular}

Table 2. Proteins with significantly increased abundance at the critical node in 0-d, 3-d, and 4-d aged rice seeds. Mascot scores $>65$ are statistically significant at $p<0.05$.

A



B

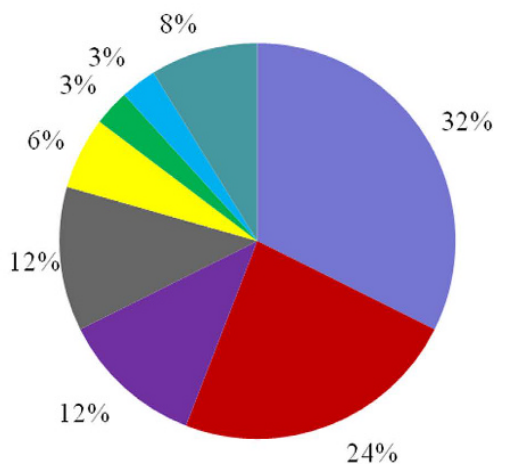

Figure 2. Classification of downregulated (A) and upregulated (B) proteins in $0 \mathrm{~d}, 3 \mathrm{~d}$, and $4 \mathrm{~d}$ aged rice seeds after imbibition for $48 \mathrm{~h}$. 


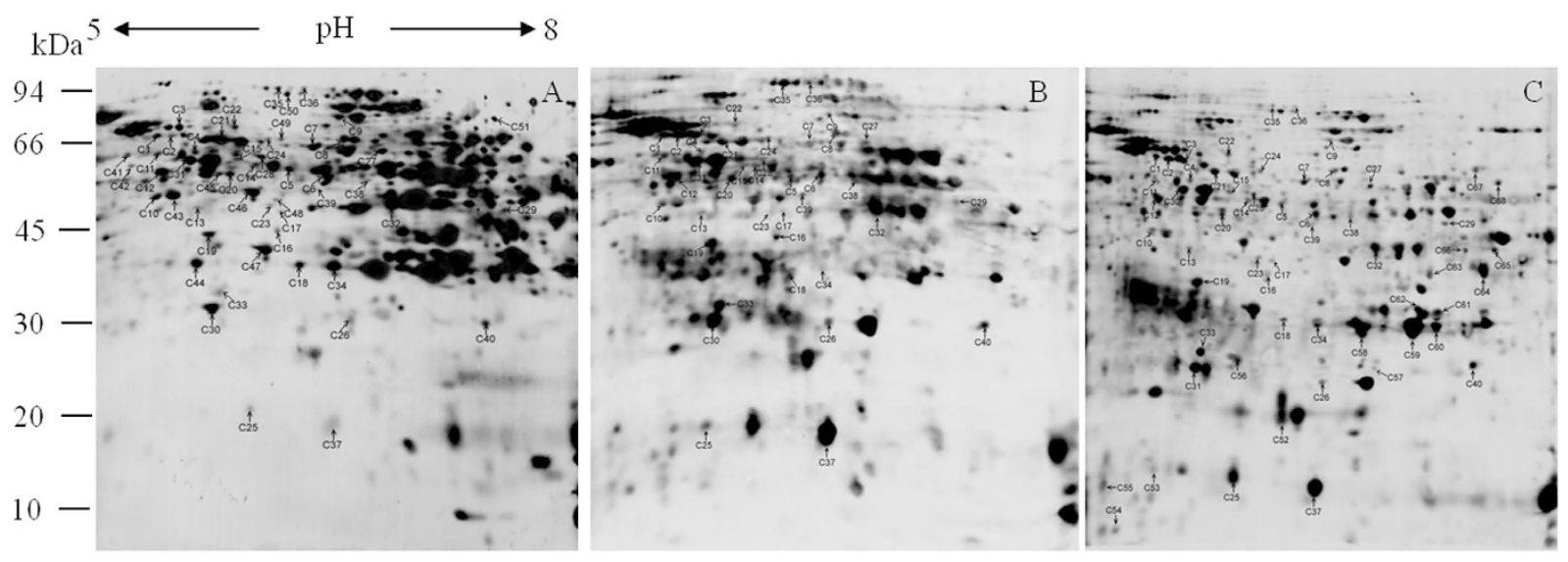

Figure 3. Two-dimensional (2D) immunoblots using antidinitrophenyl hydrazone antibody to detect carbonylated embryo proteins in $0-\mathrm{d}(\mathbf{A}), 3-\mathrm{d}(\mathbf{B})$, and 4-d (C) aged rice seeds after imbibition for $48 \mathrm{~h}$. Total $500 \mu \mathrm{g}$ protein were numbered in a preparative $2 \mathrm{D}$ electrophoresis gel and excised for MS/MS analysis, corresponding to the proteins in Tables 1,2 and 3. Number on the left represents the apparent molecular mass. Number above the gels represents the pI of separated protein spot. (C) Carbonylated spot.

and $\mathrm{SDH}$, respectively (Table 1). Mitochondria plays key roles for energy supplying during seed imbibitions. $\beta$ ATP is the $\mathrm{F}_{0}$ sector of ATPase ${ }^{30}$. The state and function of ATP synthase machinery may determine the energy supplying. $\beta A T P$ protein and $\beta A T P$ expression level was significant downregualted at the CN (Fig. 5C,G). Our results were consistent with our previous reported in purified mitochondria from the $\mathrm{CN}$ of rice seed ageing ${ }^{1}$ that ATP synthase machinery was inactive which leads the ATP supplying was inhibited at the CN. The seed of MDH1 and $\mathrm{MDH} 2$ double knockout Arabidopsis mutants had a lower content of 2-oxoglutarate during imbibition ${ }^{31}$. In the present study, the activity of $\mathrm{MDH}$ and the levels of $\mathrm{MDH} 1$ were significantly decreased and carbonylated in aged seeds compared with the control (Figs 4A and 5A), indicating that the TCA cycle was inhibited at the $\mathrm{CN}$ after seed imbibition. In addition, $\mathrm{SDH}$ is a key member of the electron transport chain complex II, which catalyzes the oxidation of succinate to fumarate with the reduction of ubiquinone to ubiquinol and participates in succinate dependent $\mathrm{O}_{2}$ consumption in the electron transport chain ${ }^{32}$. SDH1 knockout Arabidopsis mutants had a decreased activity of the electron transport chain, but an increased amount of ROS under environmental stress $^{33}$. We showed that the level of SDH1 was significantly decreased and carbonylated at the CN (Fig. 5B); these results were in agreement with our previous findings that succinate dependent $\mathrm{O}_{2}$ consumption is reduced at the $\mathrm{CN}^{1}$. The decreased activity of SDH might cause ROS accumulation and oxidative damage. Overall, these results demonstrated that the mitochondrial metabolism was inhibited at the $\mathrm{CN}$, decreasing the production of ATP and its intermediates, which are needed for seed germination and ROS accumulation.

Several proteins whose showed a decrease in proteins abundance and exhibited different carbonylation levels were observed which involved in the glycolytic pathway, including phospoglycerate mutase which catalyzes the conversion of 3-phosphoglycerate to 2-phosphoglycerate ${ }^{34}$, pyruvate decarboxylase (PDC) which catalyses the decarboxylation of pyruvic acid to acetaldehyde and carbon dioxide ${ }^{35}$, triosephosphate isomerase which catalyzes the reversible interconversion of the triose phosphate isomers dihydroxyacetone phosphate D-glyceraldehyde 3-phosphate ${ }^{36}$, enolase which catalyzes the conversion of 2-phosphoglycerate to phosphoenolpyruvate ${ }^{37}$, and pyrophosphate-dependent phosphofructokinase which catalyzes the reversible phosphorylation of fructose-6-phosphate to fructose-1,6-bisphosphate ${ }^{38}$. Interestingly, PDC gene family was induced in response to environmental stress in plants ${ }^{39,40}$. By comparison, PDC1 level showed no significant change in the aged seed (Fig. 5D). We propose that the decrease of the PDC activity (Fig. 4B) caused by carbonylation may result in deleterious downstream pathway of glycolytic metabolism, leading to a reduction of energy supplying. These results indicated that glycolytic metabolism was also reduced at the CN. 6PGD was carbonylated modification and showed downregulation in aged seed, which converts 6-phosphogluconate to ribose-5-phosphate and produces NADPH in oxidative pentose phosphate pathway (PPP ${ }^{41}$. The decrease in the activity and transcript level of 6PGD resulted in reduction of NADPH production, indicating that PPP metabolism was inhibited at the $\mathrm{CN}$. Taken together, the key members of energy supplying were downregulated and carbonylated modification at the $\mathrm{CN}$, which might cause impairment of mitochondrial, glycolysis and PPP metabolism and then lead to decrease in energy supplying during imbibition, in turn, trigger a cascade of deleterious metabolism which could contribute to the process of ageing disorders.

Proteins related to defense were downregulated at the CN (Fig. 2A). APX1 plays an important role in the antioxidative metabolism, since it catalyzes the conversion of $\mathrm{H}_{2} \mathrm{O}_{2}$ to $\mathrm{H}_{2} \mathrm{O}$ in the ascorbate-glutathione cycle ${ }^{42}$. Compared with the activity of APX, the protein and gene level showed a significant decrease at the CN (Fig. 5F,G), indicating that the antioxidative system was inhibited at the $\mathrm{CN}$. These results were consistent with previous findings in the aged seed of soybean, maize, and other species ${ }^{11-13}$. The decreased capacity of the antioxidative system could lead to ROS accumulation, reflecting the oxidative damage and increased protein carbonylation.

GST catalyzes the conjugation of the reduced form of glutathione to xenobiotic substrates for the purpose of detoxification ${ }^{43}$ and protects against oxidative damage by ROS ${ }^{44}$. In the present study, the activity of GST showed 


\begin{tabular}{|c|c|c|c|}
\hline Spot & Protein name & Accession No. & Scores \\
\hline \multicolumn{4}{|c|}{ Down-regualation } \\
\hline \multicolumn{4}{|l|}{ Energy } \\
\hline $\mathrm{C} 42$ & Vacuolar ATPase B subunit & NP_001057902.1 & 316 \\
\hline C46 & Phosphoglycerate kinase & ABI74567.1 & 899 \\
\hline $\mathrm{C} 47$ & Glucose and ribitol dehydrogenase homolog & Q75KH3.2 & 664 \\
\hline \multicolumn{4}{|c|}{ Transcription } \\
\hline $\mathrm{C} 45$ & Eukaryotic initiation factor $4 \mathrm{~A}-1$ & BAA02152.1 & 448 \\
\hline C48 & Elongation factor $\mathrm{Tu}$ & NP_001051912.1 & 415 \\
\hline \multicolumn{4}{|c|}{ Metabolism } \\
\hline C50 & Aconitate hydratase, cytoplasmic & Q6YZX6.1 & 671 \\
\hline C51 & Pyruvate kinase 1 , cytosolic & NP_001065749.1 & 194 \\
\hline \multicolumn{4}{|c|}{ Disease and defense } \\
\hline $\mathrm{C} 41$ & $60 \mathrm{kDa}$ chaperonin alpha subunit & AAP44754.1 & 215 \\
\hline \multicolumn{4}{|c|}{ Secondary metabolism } \\
\hline C44 & Lactoylglutathione lyase & BAB71741.1 & 797 \\
\hline \multicolumn{4}{|c|}{ Growth/division } \\
\hline $\mathrm{C} 43$ & Actin-1 & NP_001051086.1 & 573 \\
\hline \multicolumn{4}{|c|}{ Protein destination and storage } \\
\hline C49 & T complex protein & NP_001057876.1 & 227 \\
\hline \multicolumn{4}{|c|}{ Up-regualation } \\
\hline \multicolumn{4}{|c|}{ Protein destination and storage } \\
\hline C52 & $19 \mathrm{kDa}$ globulin & CAA45400.1 & 161 \\
\hline C53 & Cupin family protein & AAS07324.1 & 155 \\
\hline C56 & Glutelin type-A 3 & CAA38211.1 & 342 \\
\hline C57 & Glutelin type-A 1 & AAA33906.1 & 228 \\
\hline C58 & Glutelin type-A 2 & BAA00462.1 & 315 \\
\hline C60 & Glutelin type-B 5 & BAC77349.1 & 280 \\
\hline C67 & Cupin family protein & AAS07324.1 & 575 \\
\hline \multicolumn{4}{|c|}{ Metabolism } \\
\hline C55 & Proteasome subunit alpha type- 6 & NP_001049162.1 & 133 \\
\hline C59 & Glyceraldehyde-3-phosphate dehydrogenase 2, cytosolic & NP_001053139.1 & 344 \\
\hline \multicolumn{4}{|l|}{ Energy } \\
\hline C61 & Formate dehydrogenase 1 , mitochondrial & BAA77337.1 & 295 \\
\hline C65 & Pyrophosphate-dependent phosphofructokinase alpha subuni & NP_001061602.1 & 263 \\
\hline C66 & Glucose-6-phosphate isomerase, cytosolic A & BAA08148.1 & 178 \\
\hline C68 & ATP synthase subunit $\mathrm{c}$, chloroplastic & CAA48649.1 & 179 \\
\hline \multicolumn{4}{|c|}{ Unclear classification } \\
\hline C54 & Os05g0569500 protein & NP_001056364.1 & 361 \\
\hline
\end{tabular}

Table 3. Proteins with no significantly changed abundance and significant carbonylation at the critical node in 0-d, 3-d, and 4-d aged rice seeds. Mascot scores $>65$ are statistically significant at $p<0.05$.

significant decrease at the $\mathrm{CN}$ (Fig. 4E), indicating that rice seed was affected by ROS. Additionally, we observed the specific carbonylation of proteins related to oxidative stress such as HSPs and chaperonins. HSPs are encoded by multigene families ${ }^{45}$; small HSP class I $(17.9 \mathrm{kDa})$ belongs to the small HSP family, which is expressed in rice seed ${ }^{45,46}$. HSPs and chaperonins play an important role in protein folding and protect cells against stress ${ }^{47}$. Carbonylated HSPs and chaperonins were described in aged Arabidopsis seeds ${ }^{22}$. The downregulation of HSPs and chaperonins disrupted the defense system and might cause oxidative damage at the CN.

Our study revealed the carbonylation of upregulated proteins, such as SSP, at the CN. Previous studies reported that the degradation of storage proteins is associated with seed viability ${ }^{48}$ and that the seed of SSP mutants is sensitive to ageing ${ }^{22}$. In the present study, SSP displayed a significant upregulation and various experimental molecular weights at the $\mathrm{CN}$ (Figs 2B and 3). Our results suggest that the seed had a decreased ability to utilize SSPs at the CN, which might cause SSP accumulation and carbonylation. Previous studies reported that SSP might be a primary target for oxidative stress and protect other proteins for oxidative damage during seed ageing ${ }^{22,49}$. Our results suggest that the increased carbonylation level of SSP indicates the relatively high ROS levels at the CN. Our results were consistent with the decreased capacity of the antioxidant system at the $\mathrm{CN}$. 

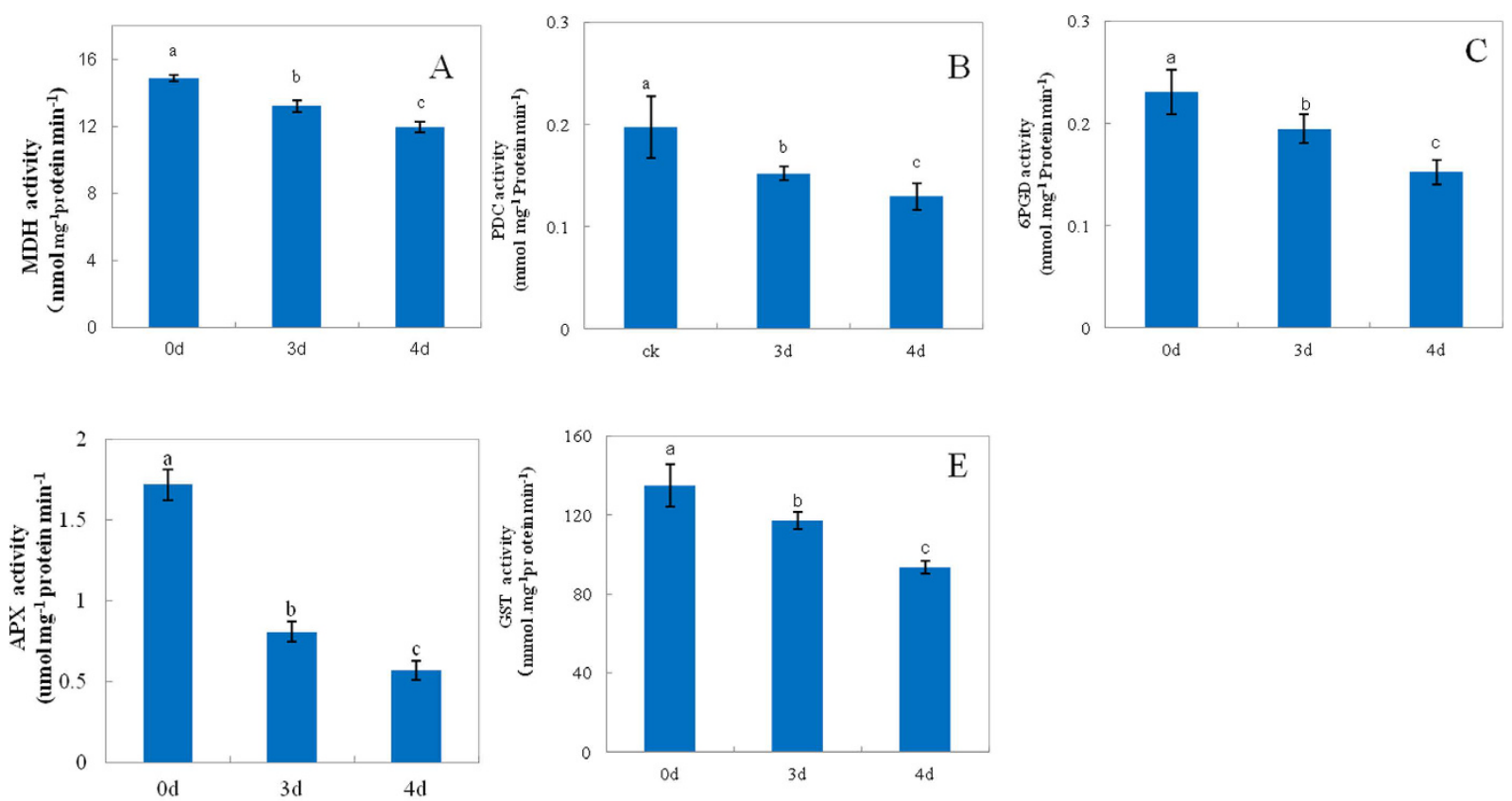

Ageing treatment

Figure 4. The activity of malate dehydrogenase $(\mathrm{MDH},(\mathbf{A}))$ pyruvate decarboxylase (PDC, (B)) 6-phosphogluconate dehydrogenase (6PGD, (C)) ascorbate peroxidase (APX, (D)) and glutathione S-transferase (GST, (E)) in 0-d, 3-d, and 4-d aged rice seeds after imbibition for $48 \mathrm{~h}$. Data represent the mean \pm standard deviation of three independent experiments. All treatments significantly differed from the control at $p<0.05(n=3)$.

\section{Conclusion}

This study revealed that oxidative stress was related to the loss of seed viability. Our findings indicated the effects of oxidative stress at the $\mathrm{CN}$, since the proteins related to energy and defense metabolism were downregulated and/ or inactivated. The ability to utilize SSPs was also reduced, leading to a rapid decline in seed viability at the P-II.

\section{Materials and Methods}

Plant material and treatments. Rice seed (Oryza sativa L. japonica nipponbare) was obtained from the Jiangxi Agricultural Academy of Sciences, Nanchang, China. Rice seeds were treated at $40{ }^{\circ} \mathrm{C}$ and $75 \%$ relative humidity for $0 \mathrm{~d}, 3 \mathrm{~d}$, and $4 \mathrm{~d}$ to decrease the germination rate by $3 \%, 8 \%$, and $16 \%$, respectively ${ }^{1}$. The embryos were extracted after seed imbibition at $28^{\circ} \mathrm{C}$ for $48 \mathrm{~h}$ in the dark, and then stored at $-80^{\circ} \mathrm{C}$ until analysis.

Proteomic and carbonylation analysis. The frozen embryos were ground with a mortar and pestle using a buffer, containing $0.1 \mathrm{M}$ Tris- $\mathrm{HCl}$ ( $\mathrm{pH} 7.5), 0.1 \%$ dithiothreitol (DTT), 2\% polyvinylpolypyrrolidone (PVPP), and $0.5 \%$ ethylenediaminetetraacetic acid (EDTA). Protein was extracted using the Tris-phenol protocol ${ }^{50}$, and then, $500 \mu \mathrm{g}$ of protein was applied to rehydrated gel strips with an immobilized linear $\mathrm{pH}$ gradient of 5-8 (BioRad, Hercules, CA, USA). The first-dimensional IEF was performed at $20^{\circ} \mathrm{C}$ on a flat-bed electrophoresis unit (BioRad) as follows: rehydration for $12 \mathrm{~h}, 0 \mathrm{~V}$ to $150 \mathrm{~V}$ in $15 \mathrm{~min}, 150 \mathrm{~V}$ to $1,000 \mathrm{~V}$ in $1 \mathrm{~h}, 1,000 \mathrm{~V}$ to $8,000 \mathrm{~V}$ in $5 \mathrm{~h}$, and $8,000 \mathrm{~V}$ until a total of $60 \mathrm{kVh}$. After IEF, the strips were: 1) equilibrated for $15 \mathrm{~min}$ in Solution A, containing $6 \mathrm{M}$ urea, $20 \%(\mathrm{v} / \mathrm{v})$ glycerol, $2 \%(\mathrm{w} / \mathrm{v}) \mathrm{SDS}, 375 \mathrm{mM}$ Tris- $\mathrm{HCl}(\mathrm{pH} 8.8)$, and 2\% (w/v) DTT, and then, in Solution B, containing $6 \mathrm{M}$ urea, $20 \%$ (v/v) glycerol, $2 \%$ (w/v) SDS, $375 \mathrm{mM}$ Tris- $\mathrm{HCl}$ (pH 8.8), and 2.5\% iodoacetamide for analyzing the proteomic profile and 2) derivatized by incubating in $10 \mathrm{mM} \mathrm{DNPH}$ for $20 \mathrm{~min}$ with gentle agitation, and then, equilibrated as described above for analyzing the profile of carbonylated proteins. The equilibrated strips were placed on SDS-PAGE using homogenous $12 \%$ (v/v) polyacrylamide gels with $4 \%$ $(\mathrm{v} / \mathrm{v})$ stacking gels (BioRad). Gel electrophoresis was performed at $250 \mathrm{~V}$ with circulating cooling using a running buffer, containing $25 \mathrm{mM}$ Tris (pH 8.3), $195 \mathrm{mM}$ glycine, and $0.1 \%(\mathrm{w} / \mathrm{v})$ SDS. The gels were stained with CBB G250 or transferred to PVDF membrane and detected with anti-DNP antibodies. Gel images were obtained using a flatbed scanner and analyzed by PDQuest 5.0 (BioRad). Spot intensity was calculated according to the relative expression volume. Spots with a fold change higher than 1.5 were excised for mass spectrometry.

In-gel digestion, mass spectrometry, and database searching. The protein and carbonylated protein that were corresponded the protein spot on $2 \mathrm{D}$ gels, were excised into $1-\mathrm{mm}^{3}$ pieces from $2 \mathrm{D}$ gels and de-stained with $25 \mathrm{mM} \mathrm{NH}_{4} \mathrm{CO}_{3}$ in $50 \%$ acetonitrile. The gels were dehydrated by adding acetonitrile and then, digested with $25 \mu \mathrm{l}$ of $0.1 \mathrm{mM}$ trypsin in $25 \mathrm{mM} \mathrm{NH}_{4} \mathrm{CO}_{3}$ for $15 \mathrm{~min}^{51}$. The excess trypsin solution was removed, and gel pieces were incubated at $37^{\circ} \mathrm{C}$ overnight in $20 \mu \mathrm{l}$ of $25 \mathrm{mM} \mathrm{NH}_{4} \mathrm{CO}_{3}$. A mixture of $1 \mu \mathrm{l}$ peptide solution 

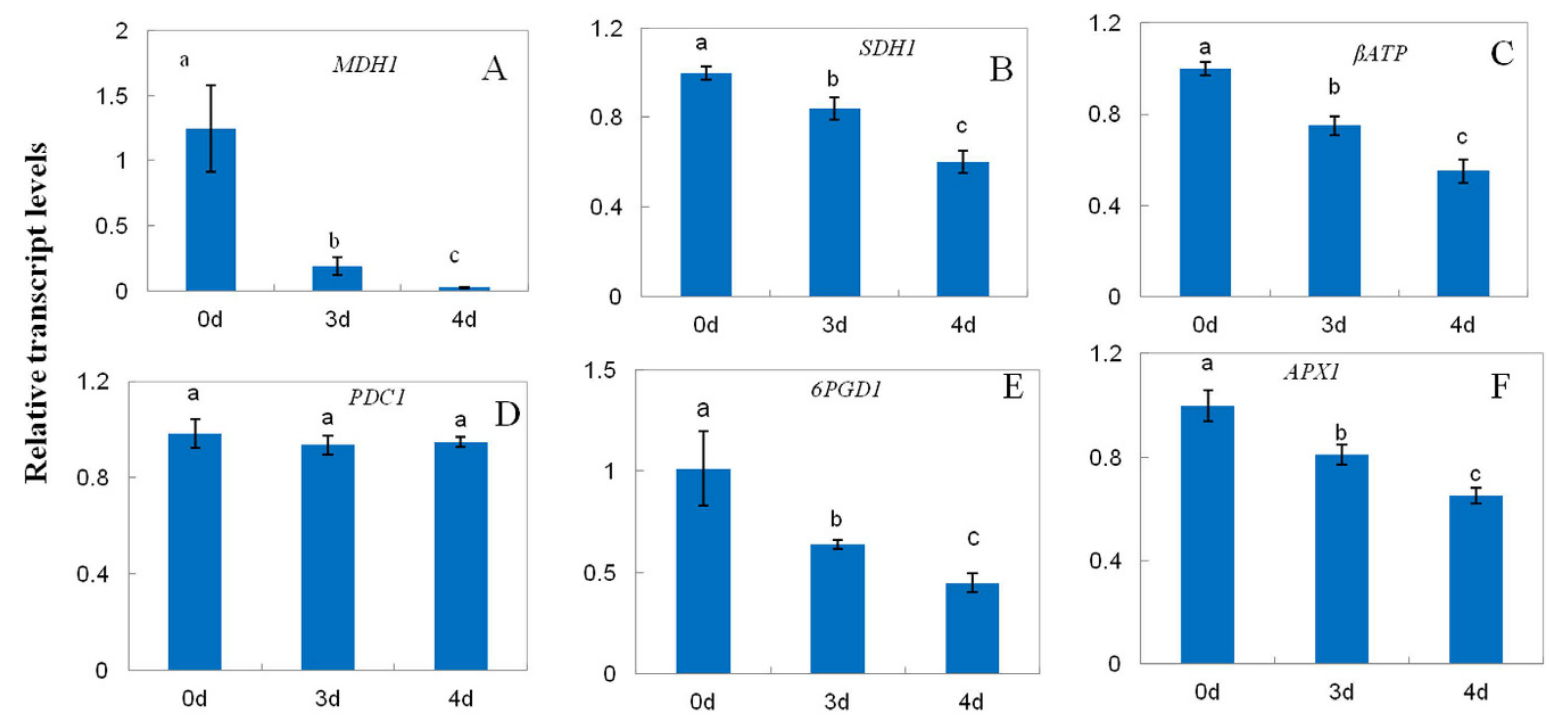

Ageing treatment

G

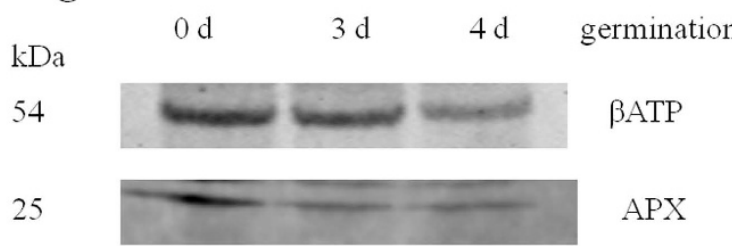

Figure 5. Relative levels of malate dehydrogenase $1(\mathrm{MDH1},(\mathbf{A}))$ succinate dehydrogenase $1(\mathrm{SDH} 1,(\mathbf{B})) \beta$ ATP synthase (C)) pyruvate decarboxylase $1(P D C 1,(\mathbf{D}))$ 6-phosphogluconate dehydrogenase $1(6 P G D 1,(\mathbf{E}))$ and ascorbate peroxidase $1(A P X 1,(\mathbf{F}))$ and abundance of beta subunit of ATP synthase ( $\beta A T P)$ and ascorbate peroxidase (APX) (G) in 0-d, 3-d, and 4-d aged rice seeds after imbibition for $48 \mathrm{~h}$. Transcript levels in 3-d and 4 -d aged seeds were calculated in relation to a value of 1.0 that assigned to 0 -d aged seeds after imbibition for $48 \mathrm{~h}$. Data represent the mean \pm standard deviation of three independent experiments. All treatments significantly differed from the control at $p<0.05(n=3)$.

and $1 \mu \mathrm{l}$ matrix solution with $1 \mathrm{mg} \mathrm{ml}^{-1}$, a-cyano-4-hydroxycinnamic acid in $70 \%$ acetonitrile, and $0.1 \%$ trifluoroacetic acid was loaded onto the AnchorChip MALDI target plate (Bruker Daltonics, Manning Park Billerica, MA, USA) and analyzed by a matrix assisted laser desorption-ionization time of flight (MALDI-TOF)/TOF mass spectrometer (Bruker Daltonics), according to the manufacturer's instructions. MS data were uploaded to the Mascot server using Biotools (Bruker Daltonics) and searched against the National Center for Biotechnology Information (NCBI) protein database $(25,010,123$ sequences; $8,625,376,125$ residues; search parameters, rice; proteolytic enzyme, trypsin; maximum missed cleavages, 1 ; fix modifications, carbamidomethyl; variable modifications, oxidation; peptide mass tolerance, $100 \mathrm{ppm}$; fragment mass tolerance, $0.5 \mathrm{Da}$ ). Spots with a Mowse score higher than 65 were considered as proteins.

Assay of enzyme activities. The activity of MDH was determined at $340 \mathrm{~nm}$ as described by Glatthaar et al. ${ }^{52}$. The activity of PDC was measured in a reaction medium, containing $200 \mathrm{mM}$ Tris- $\mathrm{HCl}$ ( $\mathrm{pH} 6.0$ ), $100 \mathrm{mM}$ pyruvate, $0.1 \mathrm{mM}$ thiamine pyrophosphate, $1.0 \mathrm{mM} \mathrm{MgCl}_{2}$, 9.0 units of alcohol dehydrogenase, and $225 \mu \mathrm{M} \mathrm{NADH}$ as described ${ }^{53}$ with minor modifications. The activity of APX was determined at $290 \mathrm{~nm}$ as described by Nakano and Asada ${ }^{54}$. The activity of GST was determined at $340 \mathrm{~nm}$ as described by Habig et al. ${ }^{55}$. The activity of 6PGD was determined in $50 \mathrm{mM}$ Tris- $\mathrm{HCl}(\mathrm{pH} 7.5)$ and $0.25 \mathrm{mM}$ NADP, started with $2 \mathrm{mM}$ 6-phosphogluconate as described by Bailey-Serres and Nguyen ${ }^{56}$.

Immunoblot analysis. Equal amounts of rice embryo proteins ( $10 \mu \mathrm{g}$ per lane) were loaded onto SDS-PAGE gels, transferred to PVDF, and incubated with $\beta$ ATP and APX antibodies. Anti-rabbit IgG was used as a secondary antibody (Agrisera, Vannas, Sweden). Immunodetection was performed using the Chemiluminescent Substrate Kit (KPL, Hemet, CA, USA).

Quantitative real-time polymerase chain reaction (qRT-PCR). Total RNA was isolated from rice embryos after seed imbibition for $48 \mathrm{~h}$ using the RNAprep pure plant kit (Tiangen, Beijing, China). Specific primer pairs (Supplemental Table 1) were designed using Primer 5 (Premier Biosoft, Palo Alto, CA, USA). qRT-PCR was 


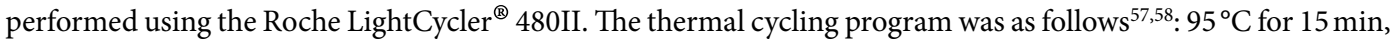
40 cycles at $95^{\circ} \mathrm{C}$ for $15 \mathrm{~s}$ and at $60^{\circ} \mathrm{C}$ for $30 \mathrm{~s}$. The gene expression of rice $U B Q 5$ was used as an internal control.

Protein concentration assay. Protein concentration was determined as described by Bradford ${ }^{59}$ using $^{-1}$ bovine serum albumin as a standard.

Statistical analysis. Data were pooled across repeated experiments. Analysis of variance in conjunction with the least significant difference test was performed by SPSS (IBM, Chicago, IL, USA). Differences were considered significant at $p<0.05$.

\section{References}

1. Yin, G. K. et al. Comprehensive mitochondrial metabolic shift during the critical node of seed ageing in Rice. Plos. One. 11, e0148013 (2016).

2. Walters, C., Wheeler, L. M. \& Stanwood, P. C. Longevity of cryogenically stored seeds. Cryobiology 48, 229-244 (2004).

3. FAO. Second report on the state of the world's plants genetic resources for food and agriculture. Commission on Genetic Resources for Food and Agriculture, Food and Agriculture Organization of The United Nations, Rome, pp. 47 (2010).

4. Börner, A., Chebotar, S. \& Korzun, V. Molecular characterization of the genetic integrity of wheat (Triticum aestivum L.) germplasm after long-term maintenance. Theor. Appl. Genet. 100, 494-497 (2000).

5. Hay, F. R. et al. Viability of Oryza sativa L. seeds stored under genebank conditions for up to 30 years. Genet. Resour. Crop Ev. 60, 275-296 (2013)

6. Hay, F. R., de Guzman, F. \& Sackville Hamilton, N. R. Viability monitoring intervals for genebank samples of Oryza sativa. Seed Sci. Technol. 43, 218-237 (2015).

7. Hintum, T. J., van De Wiel, C. C. M., Visser, D. L., Van Treuren, R. \& Vosman, B. The distribution of genetic diversity in a Brassica oleracea gene bank collection related to the effects on diversity of regeneration, as measured with AFLPs. Theor. Appl. Genet. 114, 777-786 (2007)

8. FAO. Genbank Stardards 2014. Food and Agriculture Organization of The United Nations, Rome, 36 (2014).

9. Bailly, C. \& Kranner, I. Analyses of reactive oxygen species and antioxidants in relation to seed longevity and germination. In Seed Dormancy. Humana Press. (pp. 343-367) (2011).

10. Rajjou, L. \& Debeaujon, I. Seed longevity: survival and maintenance of high germination ability of dry seeds. C. R. Biol. 331, 796-805 (2008)

11. Xin, X. et al. Proteome analysis of maize seeds: the effect of artificial ageing. Physiol. Plantarum 143, 126-138 (2011).

12. Yin, G. K. et al. Activity levels and expression of antioxidant enzymes in the ascorbate-glutathione cycle in artificially aged rice seed. Plant Physiol. Biochem. 80, 1-9 (2014).

13. Xin, X. et al. Reduced mitochondrial and ascorbate-glutathione activity after artificial ageing in soybean seed. J. Plant Physiol. 171, 140-147 (2014)

14. Wang, Y., Li, Y., Xue, H., Pritchard, H. W. \& Wang, X. Reactive oxygen species-provoked mitochondria-dependent cell death during ageing of elm (Ulmus pumila L.) seeds. Plant J. 81, 438-452 (2015).

15. Petla, B. P. et al. Rice PROTEIN 1-ISOASPARTYL METHYLTRANSFERASE isoforms differentially accumulate during seed maturation to restrict deleterious isoAsp and reactive oxygen species accumulation and are implicated in seed vigor and longevity. New Phytol. 211, 627-645 (2016).

16. Wong, C. M., Marcocci, L., Liu, L. \& Suzuki, Y. J. Cell signaling by protein carbonylation and decarbonylation. Antioxid. Redox Signal. 12, 393-404 (2010).

17. Ramallo Guevara, C. et al. Global protein oxidation profiling suggests efficient mitochondrial proteome homeostasis during ageing. Mol. Cell. Proteomics. mcp. M115.055616 (2016).

18. Qin, G. Z., Wang, Q., Liu, J., Li, B. Q. \& Tian, S. P. Proteomic analysis of changes in mitochondrial protein expression during fruit senescence. Proteomics 9, 4241-4253 (2009).

19. Havé, M., Leitao, L., Bagard, M., Castell, J. F. \& Repellin, A. Protein carbonylation during natural leaf senescence in winter wheat, as probed by fluorescein-5-thiosemicarbazide. Plant Biol. 17, 973-979 (2015).

20. Zhang, H. et al. Analysis of dynamic protein carbonylation in rice embryo during germination through AP-SWATH. Proteomics. pmic. 201500248 (2016)

21. Rajjou, L. et al. Proteome-wide characterization of seed aging in Arabidopsis. A comparison between artificial and natural aging protocols. Plant Physiol. 148, 620-641 (2008).

22. Nguyen, T. P., Cueff, G., Hegedus, D. D., Rajjou, L. \& Bentsink, L. A role for seed storage proteins in Arabidopsis seed longevity. J. Exp. Bot. 66, 6399-6413 (2015).

23. Yin, X., He, D., Gupta, R. \& Yang, P. Physiological and proteomic analyses on artificially aged Brassica napus seed. Front Plant Sci. 6, fpls.2015.00112 (2015)

24. Bevan, M. et al. Analysis of $1.9 \mathrm{Mb}$ of contiguous sequence from chromosome 4 of Arabidopsis thaliana. Nature 391, 485-488 (1998).

25. Stadtman, E. R. Role of oxidant species in aging. Curr. Med. Chem. 11, 1105-1112 (2004).

26. Møller, I. M., Jensen, P. E. \& Hansson, A. Oxidative modifications to cellular components in plants. Annu. Rev. Plant Biol. 58, 459-481 (2007)

27. Bewley, J. D. Seed germination and dormancy. Plant Cell 9, 1055-1066 (1997)

28. Narsai, R., Law, S. R., Carrie, C., Xu, L. \& Whelan, J. In-depth temporal transcriptome profiling reveals a crucial developmental switch with roles for RNA processing and organelle metabolism that are essential for germination in Arabidopsis. Plant Physiol. 157, 1342-1362 (2011).

29. Law, S. R. et al. Nucleotide and RNA metabolism prime translational initiation in the earliest events of mitochondrial biogenesis during Arabidopsis germination. Plant Physiol. 158, 1610-1627 (2012).

30. Sweetlove, L. J. et al. The impact of oxidative stress on Arabidopsis mitochondria. Plant J. 32, 891-904 (2002).

31. Sew, Y. S., Ströher, E., Fenske, R. \& Millar, A. H. Loss of mitochondrial malate dehydrogenase activity alters seed metabolism impairing seed maturation and post-germination growth in Arabidopsis. Plant Physiol. 171, 849-863 (2016).

32. Huang, S. \& Millar, A. H. Sequence diversity and conservation in factors influencing succinate dehydrogenase flavinylation. Plant Signal Behav. 8, e22815 (2013)

33. Gleason, C. et al. Mitochondrial complex II has a key role in mitochondrial-derived reactive oxygen species influence on plant stress gene regulation and defense. Proc. Natl. Acad. Sci. USA. 108, 10768-73 (2011).

34. Zhao, Z. \& Assmann, S. M. The glycolytic enzyme, phosphoglycerate mutase, has critical roles in stomatal movement, vegetative growth, and pollen production in Arabidopsis thaliana. J Exp Bot. 62, 5179-5189 (2011)

35. Agarwal, S., Kapoor, A., Lakshmi, O. S. \& Grover, A. Production and phenotypic analysis of rice transgenics with altered levels of pyruvate decarboxylase and alcohol dehydrogenase proteins. Plant Physiol. Biochem. 45, 637-646 (2007). 
36. Sharma, S., Mustafiz, A., Singla-Pareek, S. L., Shankar Srivastava, P. \& Sopory, S. K. Characterization of stress and methylglyoxal inducible triose phosphate isomerase (OscTPI) from rice. Plant Signal. Behav. 7, 1337-1345 (2012).

37. Fukayama, H. et al. Characterization and expression analyses of two plastidic enolase genes in rice. Biosci. Biotechnol. Biochem. 79, 402-409 (2015)

38. Rye, P. T. \& Lamarr, W. A. Measurement of glycolysis reactants by high-throughput solid phase extraction with tandem mass spectrometry: Characterization of pyrophosphate-dependent phosphofructokinase as a case study. Anal. Biochem. 482, 40-47 (2015).

39. Pinhero, R. G. et al. Alleviation of low temperature sweetening in potato by expressing Arabidopsis pyruvate decarboxylase gene and stress-inducible rd29A: A preliminary study. Physiol. Mol. Biol. Plants. 17, 105-114 (2011).

40. Mithran, M., Paparelli, E., Novi, G., Perata, P. \& Loreti, E. Analysis of the role of the pyruvate decarboxylase gene family in Arabidopsis thaliana under low-oxygen conditions. Plant Biol. 16, 28-34 (2014).

41. Fernández-Fernández, Á. D. \& Corpas, F. J. In Silico Analysis of Arabidopsis thaliana Peroxisomal 6-Phosphogluconate Dehydrogenase. Scientifica (Cairo). 3482760 (2016).

42. Teixeira, F. K., Menezes-Benzvente, L., Galváo-Margis, V. C. R. \& Margis-Pinheiro, M. Rice ascorbate peroxidase gene family encodes functionally diverse isoforms localized in different subcellular compartments. Planta 224, 300-314 (2006).

43. Hayes, J. D. \& McLellan, L. Glutathione and glutathione-dependent enzymes represent a co-ordinately regulated defence against oxidative stress. Free Radic. Res. 31, 273-300 (1999).

44. Moons, A. Regulatory and functional interactions of plant growth regulators and plant glutathione S-transferases (GSTs). Vitam. Horm. 72, 155-202 (2005).

45. Sarkar, N. K., Kim, Y. K. \& Grover, A. Rice sHsp genes: genomic organization and expression profiling under stress and development. BMC Genomics 10, 393 (2009).

46. Zimmermann, P. et al. Genevestigator transcriptome meta-analysis and biomarker search using rice and barley gene expression databases. Mol. Plant. 1, 851-857 (2008).

47. Morano, K. A. New tricks for an old dog: the evolving world of Hsp70. Ann. N. Y. Acad. Sci. 1113, 1-14 (2007).

48. Müntz, K., Belozersky, M. A., Dunaevsky, Y. E., Schlereth, A. \& Tiedemann, J. Stored proteinases and the initiation of storage protein mobilization in seeds during germination and seedling growth. J. Exp. Bot. 52, 1741-52 (2001).

49. Davies, M. J. The oxidative environment and protein damage. Biochim. Biophys. Acta. 1703, 93-109 (2005).

50. Islam, N., Lonsdale, M., Upadhyaya, N. M., Higgins, T. J., Hirano, H. \& Akhurst, R. Protein extraction from mature rice leaves for two-dimensional gel electrophoresis and its application in proteome analysis. Proteomics 4, 1903-1908 (2004).

51. Liu, B., Qin, F., Liu, W. \& Wang, X. Differential proteomics profiling of the ova between healthy and Rice stripe virus-infected female insects of Laodelphax striatellus. Sci Rep. 6, 27216 (2016).

52. Glatthaar, B. E., Barbarash, G. R., Noyes, B. E., Banaszak, L. J. \& Bradshaw, R. A. The preparation of the cytoplasmic and mitochondrial forms of malate dehydrogenase and aspartate aminotransferase from pig heart by a single procedure. Anal. Biochem. 57, 432-451 (1974).

53. Conway, T., Osman, Y. A., Konnan, J. I., Hoffmann, E. M. \& Ingram, L. O. Promoter and nucleotide sequences of the Zymomonas mobilis pyruvate decarboxylase. J. Bacteriol. 169, 949-954 (1987).

54. Nakano, Y. \& Asada, K. Hydrogen peroxide is scavenged by ascorbate-specific peroxidase in spinach chloroplasts. Plant Cell Physiol. 22, 867-880 (1981)

55. Habig, W. H., Pabst, M. J. \& Jakoby, W. B. Glutathione S transferases-The first enzymatic step in mercapturic acid formation. J. Biol. Chem. 249, 7130-7139 (1974).

56. Bailey-Serres, J. \& Nguyen, M. T. Purification and characterization of cytosolic 6-phosphogluconate dehydrogenase isozymes from maize. Plant Physiol. 100, 1580-1583 (1992).

57. Than, W., Qin, F., Liu, W. \& Wang, X. Analysis of Sogatella furcifera proteome that interact with P10 protein of Southern rice blackstreaked dwarf virus. Sci Rep. 6, 32445 (2016).

58. Liu, W., Gray, S., Huo, Y., Li, L., Wei, T. \& Wang, X. Proteomic Analysis of Interaction between a Plant Virus and Its Vector Insect Reveals New Functions of Hemipteran Cuticular Protein. Mol Cell Proteomics. 14, 2229-2242 (2015).

59. Bradford, M. M. A rapid and sensitive method for the quantitation of microgram quantities of protein utilizing the principle of protein-dye binding. Ann. Biochem. 72, 248-254 (1976).

\section{Acknowledgements}

This work was supported by the National Natural Science Foundation of China Program (31371713 and 31401470), the National Key Technology R\&D Program (2013BAD01B01), the Agricultural Science and Technology Innovation Program/Crop Germplasm Resources Preservation and Sharing Innovation Team. JW is supported by grants from the Australian Research Council (CE140100008).

\section{Author Contributions}

G.Y., X.L. and J.W. designed the research. G.Y., S.F., M.A. and S.W. performed experiments, G.Y., X.X., X.C., J.Z. and J.H. analysed the results. G.Y. and J.W. wrote the paper, X.X., X.C., J.Z. and J.H. helped with editing the paper before submission. All authors reviewed the manuscript.

\section{Additional Information}

Supplementary information accompanies this paper at http://www.nature.com/srep

Competing financial interests: The authors declare no competing financial interests.

How to cite this article: Yin, G. et al. Proteomic and Carbonylation Profile Analysis at the Critical Node of Seed Ageing in Oryza sativa. Sci. Rep. 7, 40611; doi: 10.1038/srep40611 (2017).

Publisher's note: Springer Nature remains neutral with regard to jurisdictional claims in published maps and institutional affiliations.



This work is licensed under a Creative Commons Attribution 4.0 International License. The images or other third party material in this article are included in the article's Creative Commons license, unless indicated otherwise in the credit line; if the material is not included under the Creative Commons license, users will need to obtain permission from the license holder to reproduce the material. To view a copy of this license, visit http://creativecommons.org/licenses/by/4.0/

(c) The Author(s) 2017 